\title{
Communicating nationalism in a changing Europe: The media coverage of Catalan's attempt at independence
}

Marcos Martínez-Solanilla, Jönköping University, Master Research Student of International Communication, mmartinezsolanilla@outlook.com

\begin{abstract}
Since 2008, Europe is immersed in a situation of political and social upheaval marked by, among other processes - such as the Brexit, the Scottish referendum on independence or the growth of new populist parties - , the strengthening of nationalism in Catalonia. In this context, the role of the media is crucial, since they are the main transmitters of what occurs abroad and, depending on how they present the information, a spread of pro-independence trends in regions with a historically strong nationalist sentiment throughout the continent can be more or less likely. In order to know the differences regarding the coverage of nationalism, this study applies a Critical Discourse Analysis (CDA) to the text present in the main article on the Catalan referendum of October 1 $1^{\text {st }}, 2017$ published online by the most-read newspapers in Portugal, Switzerland, UK, Italy, Scotland and Northeast Italy. The analysis concludes that the media not only report differently depending on the characteristics of the territory where they operate, but also that some of them use the information as a tool to indoctrinate society.
\end{abstract}

\section{Keywords}

Catalonia, Europe, nationalism, referendum, online newspapers, independence

\section{Introduction}

While the European Union continues its process of supranational integration, some of its oldest states - especially Spain, the United Kingdom and Belgium - face political challenges that could end with the independence of one of its regions, understanding as such the administrative and territorial divisions within a country regardless if they constitute nations.

The social, political and economic crisis of 2008 gave rise to a new period marked by the "social action cycles" (Tarrow, 2011, p. 342) - movements such as 5 Stelle [Five Stars] (Italy) or The Outraged (Greece) and nationalism - defined as "the ideology that proclaims the distinctiveness of a particular people and their right to self-rule in their homeland" (Esman, 1994, p. 28) -, which has proliferated in the last decade as a response to the deterioration of welfare states and both the state and global austerity policies, finding one of its maximum manifestations in the independence process of Catalonia (Spain).
These "cycles" have arisen in a world that is globalized and highly interconnected thanks to technological development, which allows both the new (mobile media, Internet, social media networks, etc.) and traditional media (television, printed media, radio, etc.) to receive and publish information at any time. However, the high competitiveness that communication companies experience and the economic decline they have suffered since the appearance of the Internet means that, sometimes, their goal is "to get their product to the largest number of consumers" (Morley \& Robins, 1995, p. 11) without attending to the criteria of informative quality.

Starting from the basis that sustainable global communication is necessary to achieve social sustainability (Orgad, 2012), it could be argued that the lack of journalistic impartiality when covering pro-independence issues, together with the actual panorama of social discontent in many states, could cause the beginning or the strengthening of similar processes in other territories. This is a real possibil- 
ity considering the emergence, since the second half of the $20^{\text {th }}$ century, of the regionalist parties, which have a strong nationalist component (Türsan, 1998) since they undertake self-government and territorial claims within established states by appealing to the distinctiveness of a collective identity in terms of language, religion, economy, geography and/or history (keating, 2013). Concretely, these parties which reach to demand, in extreme cases, the independence of the region that they represent (Dandoy, 2010) - have doubled in Europe in the last 50 years; a data whose relevance is reinforced by the fact that eight of the 28 European Union's member states have one or more regions with a historically strong nationalist sentiment (Jolly, 2015).

Knowing the informative approaches on nationalism carried out by news media outlets from different geographical areas is essential to understand the evolution and the future situation of European societies. The present study takes this into account and deals with the way in which the online version of the best-selling newspapers in certain Western European countries and regions - Portugal, Switzerland, United Kingdom, Italy, Scotland (UK) and Northeast Italy (Italy) - with different political, social and economic realities covered one of the key moments in the process of Catalonia's independence: October $1^{\text {st }}, 2017$, when the Catalan referendum was held on a turbulent day marked by clashes between voters and police officers who had a court order to close polling stations.

\section{The rise of nationalism in Europe}

The European continent has experienced a paradoxical process since the second half of the $20^{\text {th }}$ century. On the one hand, the different countries of the continent have been immersed in a process of unprecedented political, economic and social integration through their accession to the European Union. However, the number of nationalist movements has increased exponentially in the same period; a tendency that can be observed in the percentage of regionalist parties that have participated in the general elections of European countries since the 50's: in 1950, these parties accounted for $9.4 \%$ of the total; in 1960, $7.8 \%$; in 1970, 10.9\%; in 1980, $15.5 \%$; in $1990,15.4 \%$, and in $2000,20.2 \%$ (Jolly, 2015, p. 72).

As Walker Connor (1989, p. 124) explains, citizens of ethnic minorities in modern democratic states tend not to desire independence even if they do not renounce a certain ethnocratic articulation. This is due both to the progressive loss of identifying attraction on the part of the state and to the fact that economic interrelations slow these tendencies. It seems, however, that integration in global political groupings serves these parties as a guarantee of success in the case that they achieve their objectives. In this way, deeper European integration "will be associated with greater electoral support for regionalist parties" (Jolly, 2015, p. 82) since the electorate perceives in a more positive way both the economic consequences of independence and the bargaining leverage of these parties (Fearon \& van Houten, 2002; Garrett \& Rodden, 2003).

A number of authors, such as Brubaker and Smith, have remarked the importance of politics in the resurgence of contemporary nationalism. Brubaker (1996, p. 17) maintains that nationalism "is produced - or better, it is induced - by political fields of particular kinds" and, in the same line, Smith (1995, p. 68) considers crucial the "politicization of culture" as a previous step to the regeneration of the nation-state.

Both agree that nationalism - which has the capacity "to overcome internal ideological and political divisions" since "it does not determine which political doctrine its adherents should support" (Guibernau, 1998, p. 86) - tends to find a greater electoral support in times of social discontent frequently related to the bad course of the economy, what could explain "the major revival of nationalist rhetoric in most European countries" (Brubaker, 1996, p. 2) during the last decades and, specially, since the start of the crisis in 2008. 
Through this rhetoric, regionalist parties use to create a political symbolism (Smith, 1995; Armstrong, 2000) by highlighting identity elements that are exclusive of the region where they operate - related with art and history, among other areas - , in a bid "to demonstrate the possession of a unique, authentic and adequate cultural heritage and ethnic past" (Smith, 1995, p. 67).

\subsection{Scotland, Flanders and Catalonia}

Among the current European nationalist movements, those present in Scotland, Flanders and Catalonia are the ones that have experienced the strongest activity, especially since the economic crisis of 2008. The first European country that would suffer a strong debate on the incompatibility of one or more of its regions in recent years was Belgium, where, in June 2010 general elections, the pro-independence NieuwVlaamse Alliantie (New Flemish Alliance, or N-VA) won the plurality of votes, "triggering a record-setting political stalemate that left Belgium without a functioning national government for over 530 days" (Connolly, 2013, p. 52).

Shortly after, in May 2011, "the Scottish National Party (SNP) won a majority of seats in the Scottish Parliament and immediately announced plans to hold a referendum on severing Scotland's centuriesold union with England" (Conolly, 2013, p. 52). Only one year later, the Catalan parliament approved the future holding of an independence referendum and called for early elections in November 2012 with the aim of forming a majority nationalist government, aware of its probable success due to the general discontent of the Catalan population with the Spanish government.

Since 2010 the number of Catalans wanting independence has increased from approximately $20 \%$ to $45-47 \%$, depending upon the poll consulted. During this period the desire for independence has gone from a minority, mostly privately held belief to being expressed publicly. (King, 2014, p. 480)

\section{The role of international media in nationalism}

Although the international community has tried to resolve the spread of nationalism "by effectively eliminating the circumstances in which the right to self-determination equates with a right to secession and independence" (Borgen, 2007, p. 53), there has been a huge rise in nationalist movements which eventually culminated in a failed referendum in Scotland in 2014, and another in 2017 in Catalonia; a region that, still in 2019, is immersed in a struggle for independence from the rest of Spain.

Such a trend demonstrates the decrease of political influence on societal culture. This could be the result of society being immersed in a continuous flow of information through the Internet. As Kavoori and Chadha $(2009$, p. 340$)$ state, the Web "has emerged as the vehicle through which issues of identity politics are played out on a global stage", a consequence of which could be the re-articulation of a consumerist nationalism.

For the most part, this consumption is via digital versions of traditional newspapers, which is generating a "new mode of mass mediated intimacy and the formation of a new kind of collective space" (Hayes, 2000, p. 23) at local, state and international levels. At the same time, the free and easy access to these global online media outlets has boosted their growth and, as Flew (2007, p. 178) affirms, has provoked "a move in demand away from the cultural forms underwritten by the nation-state through cultural policy towards global cultural commodities".

In essence, it could be said that the media have somehow enhanced - and adapted to - the process of globalisation, which "crosses the ideological spectrum and engages social movements and politics at all levels" (Nederveen, 2015, p. 7). In this context, technological advances "have been rapidly removing geographical boundaries" (Lee, 2003, p. 3), meaning that state borders become somewhat blurred whenever a significant event concerns a particular country, so that the possibility of what is happening abroad having reper- 
cussions in one's own territory increases both the public interest in this information and its coverage by the media.

It is logical, therefore, that independence processes occupy a large space in the agenda-setting of the national media understanding as such those that operate throughout the geography of a state - due to the political instability that currently exists among the European Union's member states. For this reason, it could be argued that the almost simultaneous resurgence and rise of nationalist sentiment in Spain, Belgium and United Kingdom within the $21^{\text {st }}$ century - more specifically since 2007 , when the Scottish National Party (SNP) rose to power in the Scottish Parliament, although as a minority government would not have been possible without the extensive coverage in online newspapers, which allowed for different social sectors in diverse states to find out about each other, empathize with one another and feel supported.

This increasing social influence of the mass media at a global level shows the important role that traditional newspapers, particularly digital versions, have in shaping modern nation-states. In this regard, Hayes (2000, p. 13) details that these "would be inconceivable without mass communication technologies that extend cultural practices, symbols, and narratives to millions of people simultaneously across great distances". This media power through the Internet is the reason why intentional and subjective information coverage about the nationalist issues, such as the Catalan referendum, could jeopardise the state unity, since "interpretations are open to any number of interventions or interferences along the way and these include everything from the cultural symbols associated with the individual or group to the context of that communication" (Patel, Li \& Sooknanan, 2011, p. 17).

A clear example in this regard is the coverage that Catalan and Spanish TV channels and newspapers did on the independence referendum held in Scotland in 2014. Castelló, León-Solís and O'Donell (2016) studied how certain Barcelona and Madrid based media informed about this political moment and concluded that both invested "significant resources in "mapping' Scotland for their readers" (ibid, p. 160). In this way, while the Spanish media included in the analysis (the public television channel Lal, which belongs to TVE; and the dailies El País and El Mundo) characterized the Scottish referendum as, for example, an "adventure" or a "bourgeois nonsense", the Catalan (TV3 and the newspapers La Vanguardia and Ara) framed most of their publications in favor of the Scottish independence even identifying as "the hero of the Catalans" to the then Prime Minister of the United Kingdom, David Cameron, for allowing the referendum.

However, despite carrying out an information coverage far superior to any other state, Spain was not the only country where the media covered the facts according to certain social objectives. The main newspapers of the United Kingdom, for example, informed about the independence process as if it were happening far away in another country and left the front pages to other issues even on the day of the referendum (Williamson and Golding, 2016), trying to reduce, in this way, the social impact of the events. A similar dynamic followed the French media, which, according to Revest (2016), also narrated the facts as if they were taking place in a distant universe and, in addition, their information often highlighted the inviolability of nation-states in an attempt to maintain the statu quo both in France and the European Union.

In contrast, and as expected, the Scottish media carried out a broad coverage of the process and, although their information on the referendum was fairly balanced, some dailies included frames mainly related to identity - which alluded to the distinctiveness of Scottish citizens or the common characteristics and history that the Scots share with the rest of the UK - and to self-determination, both for and against independence (Dekavalla, 2016).

Together with the impartiality that the cultural context can provoke in the media, it is necessary to point out that the quality 
of information expressed in the communication industry today is in jeopardy since, as Morley and Robins (1995, p. 11) affirm, "driven now by the logic of profit and competition, the overriding objective of the new media corporations is to get their product to the largest number of consumers".

Thus, it could be said that the contribution to sustainable information on such sensitive issues as nationalism is in danger today. An incorrect contextualization of this type of conflicts could lead to similar outcomes in many other European territories where there is also a nationalist sentiment: In the European Union, there are eight countries with one or more regions in which part of the population wants independence (Spain, Italy, UK, France, Finland, Belgium, Denmark, Germany) and, in five of them, there are regionalist parties that participate in the general elections (Spain, UK, Italy, Finland and Belgium) (Jolly, 2015, p. 26-28).

\section{Methodological and theoretical framework}

This piece of research applies the framing theory and the principles of Critical Discourse Analysis (CDA) to the linguistic content present in the main article related to the Catalan referendum published online by the best-seller newspapers in the previously mentioned European countries and regions.

\subsection{Critical Discourse Analysis (CDA)}

Van Dijk (1995, p. 17) states that the practice of CDA as a method of research can be defined as "the general label for a special approach to the study of text and talk, emerging from critical linguistics, critical semiotics and in general from a socio-politically conscious and oppositional way of investigating language, discourse and communication".

For the Critical Discourse Analysis, discourse is the means by which ideologies and belief systems find their way in people's consciousness (Hodge \& Kress, 1988, p. 119). In this way, the study of the journalistic texts through this method allows the researcher to discover how "speakers and authors use language and grammatical features to create meaning, to persuade people to think about events in a particular way, sometimes even to seek to manipulate them while at the same time concealing their communicative intentions" (Machin \& Mayr, 2012, p. 1).

In the present study, this method is applied following the CDA approach formulated by Fairclough, who assumes the notion of the multifunctionality of language in texts (Titscher, Meyer, Wodak, \& Vetter, 2000) understanding that discourses and texts are socially constitutive: "Language use is always simultaneously constitutive of (i) social identities, (ii) social relations and (iii) systems of knowledge and beliefs" (Fairclough, 1993, p. 134). Concretely, the following CDA tools are used:

1 Over-lexicalization: with this tool it is possible to analyze if there exists in the text "an abundance of particular words and their synonyms or where there is evidence of over-description" (Hansen \& Machin, 2013, p. 123), which could imply the use of framing to highlight certain ideas in the news articles.

2 The use of pronouns: pronouns like "us", "we", and "them" create social differentiation. "Knowledge about the other is fundamental for realizing and articulating one's self-identity. To understand and define ourselves, the individuals and groups (communities, nations-states, etc.), we need an other to relate to, and to distinguish ourselves from" (Orgad, 2012, p. 111).

3 Quoting verbs: whether they are metalinguistic, descriptive, transcriptive, metrapropositional or neutral. According to Machin and Mayr (2012), the use of one verb or another influences in the mind of the reader the character of the individuals that the readers are being informed about.

4 Lexical choices: they allow knowing what the journalist's intention is when selecting a specific word and not one of its synonyms. 


\subsection{Framing theory}

Several authors have studied the framing theory, such as Entman (1993), McCombs (2014), and De Vreese (2005). According to Entman (1993, p. 52), "to frame is to select some aspects of a perceived reality and make them more salient in communicating text, in such a way as to promote a particular problem definition, causal interpretation, moral evaluation and/or treatment recommendation".

McCombs maintains that the term framing consists of analyzing "how objects of attention in messages - issues, political figures, or other topics - are presented" (2014, p. 59). Moreover, the author assures that, through the frames, the media "influences our attitudes and opinions and even our behavior" (2014, p. 59). De Vreese (2005, p. 51) agrees with McCombs and states that through framing "the media may shape public opinion [...] in particular ways".

It could be said that framing theory serves to discover in what way the media contributes to cultural hegemony, which occurs when the different frames of journalistic messages are so dominant that the recipients accept them without hesitation. The concept of "cultural hegemony" was developed by Antonio Gramsci (2011) in his attempt to analyze the social classes and the superstructure and, with this term, the author makes reference to the power that dominant classes perform over society, which is culturally diverse.

Taking into account this theory during the content analysis is fundamental, since the detection of the frames will allow discovering which ideas each newspaper tries to transmit to its readers and what is the cultural hegemony to which they aspire through these articles.

\subsection{Sample selection and research questions}

The research focuses on the main news articles related to the Catalan referendum published online on October $1^{\text {st }}, 2017$ by four national newspapers - Correio da Manhã [Morning Mail] (Portugal), The Sun (United Kingdom), Corriere della Sera [The Afternoon Mail] (Italy), and 20 Minuten
(Switzerland) - and two regional ones: The Daily Record (Scotland, UK) and Il Gazzettino [The Gazette] (Northeast Italy, Italy). In this study, only their online versions are considered, since this type of publication can be easily read from anywhere in the world and, therefore, can have a greater social impact than printed newspapers on the global scale (Peña-Fernández, Lazkano-Arrillaga, \& García-González, 2016; Thadeshwar \& Joglekar, 2016).

These specific media outlets were selected for this study because, during 2017, they were the best-selling newspapers in the territories in which they operate - with the exception of 20 Minuten, that is for free but also the most-read Swiss daily -, so their analysis would serve as a representative sample of the information received by the population in each area (Correia \& Martins, 2018; Meier, 2018; Firmstone, 2018; Mancini \& Gerli, 2018). Therefore, the selection of these specific media outlets allows the possibility to learn about the informative treatment that Catalan nationalism had in the national media of countries that do not have internal political problems related to independence movements (Portugal and Switzerland), in national media of countries that have this type of conflict (UK and Italy), as well as in the media that operate, exclusively, in regions with high independence feeling (Scotland and Northeast Italy).

In this sense, it is necessary to clarify that all the newspapers included in the analysis - except the Corriere della Sera, which presents a Berliner format - are tabloids and, therefore, "are aimed at common people" in terms of content and style (Johansonn, 2007, p. 16). The selection of popular/tabloid dailies over quality/ broadsheet newspapers is something to keep in mind when analysing the articles due to the potential implication that this supposes in relation to the use of language and the framing of the Catalan referendum.

Most of these newspapers published several news articles related both directly and indirectly to the events that took place in Catalonia on October $1^{\text {st }}, 2017$. However, in order to carry out a deeper analysis of 
the information, this study focuses only on one article per newspaper, which corresponds to the main information about the Catalan referendum that each daily published during the day when it was held. The rest of the publications, in general, reported isolated data about the conflict or showed realities indirectly related to it, such as the reaction of the Barcelona football club players or the European Union's response to these altercations.

Once the analysis is finished, the research questions that this study aims to answer are the following:

, RQ1: How did the analyzed newspapers cover the attempt of independence in Catalonia?

, RQ2: What are, if any, the differences between them?

, RQ3: Is the representation they carry out related to the socio-political reality of the territory where they are situated?

\section{Results}

The conducted analysis allows answering the three research questions and shows that the six newspapers covered the events that occurred during the Catalan referendum, held on October $1^{\text {st }}, 2017$, in different ways and with different intentions, although some of them share similarities.

\subsection{The Sun and Corriere della Sera}

The best-selling national newspapers in the United Kingdom and Italy (The Sun and Corriere della Sera, respectively) countries where there are one or more regions with pro-independence aspirations - show in the main online article dedicated to these events a protective position of the state unity in the territories where they operate, while they are simultaneously aware of the social repercussion that the independence of Catalonia could have in both countries. However, each uses different informative approaches.

The information published by The Sun (Sandeman, 2017) highlights three frames through the over-lexicalization, the lexical choices and the quoting verbs: 1) the ag- gressiveness of Spanish agents against the voters, 2) the suffering of citizens and 3) the "chaos" Catalonia is immersed in.

The article makes a reiterative use of two concepts: "violence", a word included 11 times, and "independence", a term that appears on eight occasions, which makes the reader correlate the attempt of independence with the violence used by the Spanish Government in response to this situation. Furthermore, the term "violence" is often replaced by synonyms full of sensationalist connotations, such as "pain", "chaos", "human rights violations", "brutality", "repression", "force" and "hostility", so that police actions are highlighted. However, Catalan voters are victimized through the use of qualifying adjectives, such as "peaceful protesters", "unarmed civilians" or "defenceless population", as well as through the use of certain verbs that emphasize the sense of violence on the part of the authorities of Madrid: "Hundreds were hurt as riot police attacked peaceful protesters and unarmed civilians"/"[Puigdemont] was forced to vote elsewhere following the police raid".

These ideas are also reflected in the quoting verbs present in the article: $\mathrm{Al}$ though many of them are neutral - those that "introduce saying without evaluating it explicitily" (Machin \& Mayr, 2012, p. 59) - and transcriptive - those that "mark the development of the discourse" (Machin \& Mayr, 2012, p. 60) - , the author also makes use of metapropositional verbs - defined as the ones that "mark the author's interpretation of a speaker" (Machin \& Mayr, 2012, p. 60) - which connote that the Spanish government leaders are authoritative and the Catalans are defenseless: "The leader of Catalonia has claimed the region has 'won the right' to independence"/ "[The deputy prime minister of Spain] accused the Catalan administration of irresponsibility"/ "Brit minister Liam Fox condemned 'the violence' meted out to Catalan voters".

The exaltation of the violence in this information already appears in the antetitle "The pain in Spain", and the frames of the text are evidenced in the article's subtitle, that, far from contextualizing the 
facts, just includes a statement made by the then president of Catalonia "Catalan president says cop violence "will shame the Spanish state forever'”), and affirms that 840 people were injured by the police officers without mentioning the number of wounded policemen that the Ministry of the Interior announced on the same day: 39 officers, a number that rose after the total count the following day to 431 (Jiménez, 2017).

On the other hand, the text includes declarations of both British and Scottish politicians who condemn the police actions and make a repeated use of the pronoun "we": "[Brit minister Liam Fox] said: 'I think we must regret violence that we have seen. We can all condemn the violence"”/“[SNP leader Nicola Sturgeon] saying: 'Regardless of views on Independence, we should all condemn the scenes being witnessed". Thus, the daily does an explicit differentiation between the "I" and "the other"; between the Spaniards, represented as aggressive, and the British, presented as democratic. The contrast between both countries is also implicitly reinforced, since the inclusion of these two specific actors in the article - Liam Fox and Nicola Sturgeon embodying the UK and Scotland, respectively - reminds the reader of the role that the state and regional governments played in the peaceful development of Scotland's referendum on independence.

Consequently, the text seems to serve as a warning to the national population of the repercussions that the independence movement has had in Spain, and, through the use of the pronoun "we", tries to indoctrinate, differentiating the country where it operates from the "anti-example" (Spain). This attempt to soften any social repercussion that the Catalan referendum could have in the United Kingdom reflects the center-right political stance of The Sun and its current support for the Conservative and Unionist Party.

The information published by the Corriere della Sera (Cazzullo, 2017), whose title "Referendum in Catalonia, the chain of errors" uses a much less shocking language than the British, shows a critical stance to- wards all the actors in the conflict. In this way, the subtitle - in which it is said that "the governments of Madrid and Barcelona have launched against each other as two daredevils" - suggests that neither the Spanish or Catalan governments acted appropriately; a balanced stance that can be related to the newspaper's centrist political position. However, although the author uses certain lexical choices to condemn the violence of the Spanish government which is said to be "very weak" and that, with the actions taken during the referendum, has shown its "ferocious face" - the ideas that the Catalans are extremists and responsible for the situation are the most repeated and highlighted ones in the text through the over-lexicalization, the lexical choices and the quoting verbs.

Thus, the supporters of an independent Catalonia are mentioned in the text as "separatists", "Catalan extremists", "noisy minority" and "uncertain majority", while the independence process itself is defined as a "hasty and failed secession". Furthermore, the author uses certain verbs that enhance his criticism towards the independence movement in general: "Public opinion strongly opposes secession, except from the Basque Country to Galicia, where the separatist movements have raised their heads, ready to complete the disintegration of Spain"/"[The Barcelona football club] has contributed to exasperate the minds, promoting the separatist cause (...)". Nevertheless, in regard to the quoting verbs, the information only includes two neutral verbs ("to express" and "to say"), since it does not present textual quotes from the actors involved in the events or make reference to them in the third person.

The criticism of the Catalan independence movement is also evident in the second paragraph of the text, which the author uses to highlight the idea that the autonomous community of Catalonia would not be what it is today without the rest of Spain: "Catalonia is not a land oppressed by a conqueror. It is the richest region of Spain, something that has achieved thanks also to the sweat and, sometimes, the blood of the Andalusian workers, the masons of Extremadura, the workers of $\mathrm{La}$ 
Mancha or the workers from the poorest regions". This criticism is also observed later on, when the journalist says that the Barcelona football club, "more than a football team", is "a constituent element of the Catalan identity and its international brand" due to the active role of its players in the Catalan independence campaign.

In this way, the information highlights two ideas in an attempt to create "cultural hegemony" (Gramsci, 2011) in Italy: 1) The pro-independence Catalans are extremists, and 2) the pro-independence Catalans are mainly responsible for the situation. With this framing, the newspaper makes Italians to relate independence with extremism, preventing the possibility that a independence conflict starts in some of its regions.

Ultimately, the reading of this information gives the impression that the newspaper urges to resolve the conflict as soon as possible, perhaps, for fear that something similar may occur in regions with a certain independence feeling in northern Italy. This desire seems evident at the end of the text, in which the author comes to propose a solution to the Catalan conflict: "Today [the king] Felipe is called to save the unity of the nation [nation-state]. And the only way he can do this is to favor the opening of a constituent process, promoting the election by universal suffrage of an assembly that drafts a new federalist pact".

\subsection{The Daily Record and Il Gazzettino}

As for the best-selling newspapers of Scotland (The Daily Record) and Northeast Italy (Il Gazzettino) - regions with a high nationalist sentiment - both take advantage of this information in their digital versions to enhance to the reader the rejection to the state repression of Catalonia and the empathy towards the Catalans; ideas that constitute the frames of both texts.

The only information published by the Scottish newspaper (Colley, 2017) focuses on the violent acts that took place in Catalonia during the referendum and, through the over-lexicalization, the lexical choices and the quoting verbs, frames two main ideas: 1) The Catalan citizenship suf- fers aggression for wanting to vote, and 2) the Spanish government is authoritarian.

Some lexical choices reveal a certain dramatization of the facts in order to generate impact on the readers: the author writes the word "riot" twice to represent the general situation of Catalonia on that day; "fears of bloodshed" to explain what Catalans were worried about before voting; and, when it comes to the explanation of what happened between the police and voters, the journalist uses nouns such as "repression" or others accompanied by qualifying adjectives, such as "shocking scenes", "shocking images" or "chaotic scenes". These words are already present in the first line of the article. In fact, the term "riot" is included at the beginning of the news headline ("Catalonia riot cops storm polling stations and 'fire rubber bullets at voters' in bid to stop banned Independence referendum"), and the subtitle begins with the words "shocking scenes" ("Shocking scenes have unfolded across the Spanish region and 38 people have so far been treated by emergency services"). In this way, the newspaper tries, with both these lexical choices and the over-lexicalization, to get a shocking and emotional text from its beginning to influence the Scottish public opinion to be more critical in relation to the Spanish governmental actions carried out in Catalonia; a purpose that is easily attainable since the impartial information in a territory that shares certain similarities with Catalonia due to its recent history can make people find their own interests and their own situation, which creates empathy.

In regard to the quoting verbs, most of those used in the text are neutral, though there are three cases in which metapropositional verbs are used and, with them, the author portrays the Spanish Government as more authoritative and powerful than the Catalan: "In June this year, the new Catalan president, Carles Puigdemont, announced plans for this Sunday's referendum" / [...] Madrid refused to accept the result of what the government claims is 'illegal' referendum". On the other hand, the text does not include pronouns such as "we", "them" or "us", so that a social dif- 
ferentiation between the Scottish and the Catalan societies is not established. In this way, the author eliminates barriers between both populations and enhances the feeling of empathy towards the Catalans.

However, despite highlighting the suffering of the Catalans throughout the article, the lack of allusions to the legality of the referendum, together with the explicit mention of its illegality when the Spanish government's stance is reflected, could be interpreted as a rejection to the Catalan independence on the part of the tabloid. Instead, it seems to support rather a political devolution process in Catalonia, understanding as such "the creation or strengthening -financially or legally- of subnational units of government" (Rondinelli, Nellis, \& Cheema, 1984). This interpretation is feasible if it's considered that The Daily Record is strongly pro-Labour and critical with both the Scottish National Party (SNP) and the independence of Scotland, and that it was supportive of the Scottish devolution referendum held in 1997 (Hutchison, 2002).

Finally, it is necessary to point out that this text does not carry out a correct contextualization of the events that occurred during the referendum and, furthermore, some of the data that the text provides about the history of Catalonia are not correct: Catalonia is referred as an independent country and it is said that it was a Kingdom until 1715, but, actually, Catalonia is an autonomous community and the Kingdom that is spoken about in this article was the Crown of Aragon, of which Catalonia was a part. This misinformation, which aims to support the creation of the Catalan state, can lead to serious social consequences because it implies the radicalization of opinions, the disappearance of empathy by other points of view and, consequently, the difficulty of reaching consensus. “(...) divisions may be deepened and exacerbated if minority media function as self-enclosed ghettos" (Mihelj, 2011, p. 9).

The main article published by the right-wing tabloid Il Gazzettino on the Catalan referendum (Evangelisti, 2017) shows a position favorable to Catalonia in detriment of the Spanish Government and frames two main ideas: 1) The Catalans have gone from being free to being attacked and, now, they live in an occupied territory, and 2) the Spanish government is aggressive and has shown, with its actions, that it is finished.

The author makes use of the over-lexicalization in the text with the aim of highlighting both frames, which is carried out by including different words and adjectives with a similar meaning. In this way, through the lexical choices, the journalist remarks the high participation rate in the referendum: "a full Plaza de Cataluña [Square of Catalonia]", "day of great mobilization"; the pacifism of Catalan citizens, who are referred as "normal people", "unarmed people" and "ordinary non-extremist citizens", and are said to have defended themselves from the police in a "passive" way; the suffering of the voters: "confiscated ballot boxes", "cruel and disturbing [situation]", "occupied schools", "bloody faces", "broken arms", "screams", "fear"; the violence used by the state security forces and the situation that this provokes: "excesses of the police", "very tough police actions", "very strong reaction", "chaos", "day of madness", "very dangerous conflict"; and the condemnation of the action carried out by the central government: "great defeat of the Spanish government", "international media disaster", "communicative suicide".

These ideas are summarized in the title of the article: "Catalonia, tear in chaos. On Tuesday the general strike", in which the autonomous community is referred as a victim immersed in a fatal situation caused by Spain, and the reader is warned that despite this, the Catalan population will continue its fight for independence the day after the events by going on a general strike.

In regard to the quoting verbs, all of them present neutral structures formed with the verb "to say", except two that are metapropositional: the author uses the verb "to consider" to question the decision of the Spanish government to declare the referendum as illegal ("The referendum on Catalan independence that the Span- 
ish Supreme Court considered illegal“), and the verb "to explain" to introduce the words that the then president of Catalonia addressed to the citizens on the referendum's night from the building of the regional government; a verb that conveys the idea of proximity and dialogue between the political leader and the population.

In this sense, it is necessary to point out that the journalist uses a series of verbs that connote something more than what they denote and with which the frames of the text are reinforced. Thus, the inclusion of certain verbs extols the bad performance of the central government: "[The Spanish prime minister] said he was still ready for dialogue"; the success of Catalan citizens: "People line up in front of schools to avoid it [the requisition of the ballot boxes] and, in Diputaciò street, they succeed"; and both the violence of the Spanish police and the suffering of the voters: "(...) the police and the Civil Guard beat women and the elderly. In some cases, they are thrown down the stairs; in others, they are kicked. They [the policemen] even charged against the firemen in a small town and fired rubber bullets while the citizens of Barcelona shout 'we will vote'”. In addition, on one occasion, the newspaper shows its support for the words expressed by the spokesman of the Catalan community, Jordi Turull, who is said to "be in his right to speak of 'international scandal'".

The support for Catalan independence is also clear if it is taken into account that the text includes three statements made by pro-independence actors - the then president of the autonomy, the spokesman of the Catalan community, and a voter - while it only reflects a brief statement from the opposite side made by the then Spanish Prime Minister, in which the firmness of the government's position is highlighted: "A clear statement by Rajoy at the end of the afternoon: 'The rule of law continues being strong'”. In the same line, the text only provides the data of voters injured during the referendum, without mentioning the number of police officers assaulted, which shows a selection of reality in favor of Catalonia. In addition, far from offering a contextualization of the conflict so that the reader can interpret the facts, the author makes subjective descriptions in which the positive side of Catalonia and the negative side of the Spanish government are exalted: "Barcelona, the city of freedom, really offers scenes of a country that is occupied". Thus, it can be observed how the newspaper selects a part of reality and exposes it as truth; something that is aggravated by the absence of contextualization, which prevents the reader from understanding the facts more broadly.

Ultimately, it's necessary to highlight the correlation between the newspaper's support for Catalan independence and its sympathy towards the Lega Nord [North League], that originally was a right-wing regionalist political party that sought to achieve the independence of the fictional Padanian state - which would include, approximately, the northern half of Italy - in a bid to get separated from "a South decried as attended, corrupt and mafia" (Pouthier, 2010, p. 583).

\subsection{Correio da Manhã and 20 Minuten}

The information carried out online by the leading newspapers in Portugal (Correio da Manhã) and Switzerland (20 Minuten) - countries without independence conflicts - show great differences.

The main information about the Catalan referendum published by the Portuguese newspaper (Correia \& Figueiredo, 2017) offers a general map of the facts in which both positions of the conflict are represented through the statements of different actors, as well as the data related to the facts. However, there are certain nuances that connote a position that justifies the actions of the Spanish government.

The text presents a certain over-lexicalization related to the idea that the voting carried out in Catalonia was not legal, so that the adjectives "illegal" and "prohibited" appear constantly throughout the article as qualifiers of the word "referendum". As for the lexical choices, most of them show that the facts are narrated in a neutral way, which becomes evident, for example, when talking about police actions against the Catalan population: "The images show violence" / "The Spanish 
police fired rubber bullets on protesters in Barcelona”. In this sense, the newspaper generally does not dramatize what happened and just transmits the facts as they have occurred, but there is a case in which the lexical choices used highlight the aggressive behavior of the demonstrators ("The police officers were forced to run and enter their cars to protect themselves from the rain of stones thrown at them by the Catalans"), which can be interpreted as a justification for police actions against voters.

The heading ("The yes to independence wins with $90 \%$ of the votes in Catalonia") highlights that 90 percent of Catalans voted in favor of independence; a fact that serves to attract the reader's attention, but which is immediately questioned in the subtitle ("The illegal referendum degenerates into violence, 844 people and 33 police officers have been injured"), since it is reported that the referendum was illegal. In addition, the title does not mention the police actions in Catalonia and, in the subtitle, it is said that both Catalan voters and police officers were injured.

Correio da Manhã stands out for the inclusion of a high number of statements made by actors involved in the conflict the then president of Catalonia, the Spanish prime minister and a Portuguese politician, among others - who are for and against the independence of Catalonia, what can be interpreted as another feature of impartiality.

Most of these statements are introduced by neutral ("to say" and "to ask") and transcriptive ("to add") quoting verbs. However, it is necessary to point out the use of metrapropositional verbs when referring to the statements of the then Spanish prime minister and Catalan president: the first is frequently introduced by the verbs "to affirm" and "to declare", that connote a firm and solid position; the second, on the other hand, is only introduced once by the verb "to declare", with this verb replaced by others such as "to announce" and "to criticize", which reflect a more abstract, defensive and non-argumentative stance. In addition, the statements made by the Portuguese political party Bloco de
Esquerda [Left Block] about the violent actions carried out by the Spanish police are introduced by the verb "to condemn", which conveys the idea that Portugal rejects the aggressiveness experienced in Catalonia, despite the fact that the text does not include pronouns like "we" or "them" in order to create social differentiation explicitly.

The text does not just provide numerical data but contextualizes them, allowing the readers to draw their own conclusions. For example, the author speaks about the number of people injured by Spanish police officers but also adds that, of them, only one is in a serious condition and details the number of wounded policemen.

The little sympathy for Catalan independence becomes evident in the final part of the text, where the newspaper includes a section entitled "The Spanish Media Association classifies the referendum as a 'threat'". It is composed of numerous statements of this organization through which it is highlighted that the Constitution of 1978 brought to Spain a period of peace and that journalists who assume the sovereignty discourse are suffering pressures in Catalonia. In this way, this media outlet shows the negative side of Catalonia, which is presented as a repressor of those who do not share the independence ideals and is shown to be primarily responsible for the end of the peace initiated in Spain with the Constitution.

Ultimately, it could be understood that, unlike the newspapers analyzed so far, the more relaxed social and political situation of Portugal in terms of independence issues allows the newspaper to deal with the events that occurred in Catalonia according exclusively to its traditional centre-right stance, supporting in a more balanced way unity rather than territorial division.

In contrast to the Portuguese daily, the main information published by the free Swiss newspaper 20 Minuten (Knüsel, 2017) focuses exclusively on the violent events that took place in Catalonia during the referendum and highlights two frames through the over-lexicalization, the lexical choices and the quoting verbs: 1) the vio- 
lent character of the Spanish agents and 2) the suffering of the Catalan citizens.

Some of the lexical choices show a certain dramatization of the facts, what can be interpreted as an attempt to generate impact on the reader and attract its attention: instead of other more neutral nouns, the text includes the word "brutality" twice to refer to the police action and "riots" to express the general situation lived in Catalonia on that day. Furthermore, the article presents a number of qualifying adjectives that highlight the violent nature of the agents: "massive force", "massive police violence", "aggressive [policemen]"; the suffering of the Catalans: "affected people", "afraid [citizens]"; and the seriousness of the conflict: "terrible [facts]", "unreal [situation]", "sad conclusion".

In the same line, a series of verbs with specific connotations reinforce these frames by extolling the pacifism of the Catalan side: "She queued for four hours to express her opinion" / "[The Catalan regional police] have behaved calmly"; and both the police violence and the victimization of the voters: "[The police] even beat old people"/“(...) the police would confiscate the urns"/ "(...) between ten and twenty officers of the Civil Guard appeared" / "The citizens] were attacked and beaten by the police" /"He couldn't vote" /“(...) the Spanish police attacked Catalans who wanted to vote".

The newspaper's stance towards the events is already visible at the beginning of the article: the news headline ("Nobody expected such brutality") highlights the police violence and predisposes the reader to interpret the information according to this idea. This perception of aggressiveness is increased by the fact that the title consists of a personal statement apparently provided by someone involved in the conflict, what humanizes the text and generates in the reader both a feeling of informative proximity and sympathy towards the Catalans. Immediately after, the subtitle offers a simplified description of the facts that completes the meaning of the article's heading: "With massive force, the Spanish police attacked Catalans who wanted to vote in the referendum".
As for the quoting verbs, all of them are neutral ("to say", "to ask", "to speak", "to tell") except the metapropositional "to complain", through which the only declaration of the Spanish government included in the text is introduced in the third person: "The Spanish police also has victims to complain: as the Ministry of the Interior tells on Twitter, eleven officials have been injured". It can be interpreted that the inclusion of this phrase in the last paragraph, after remarking the 'brutality' of the Spanish side throughout this piece of news, attributes to the quoting verb an ironic connotation in a bid to criticize any Spanish government's attempt to indirectly justify the use of force.

On the other hand, the information which does not include pronouns like "we" or "them", so that a social differentiation between the Swiss and the Spanish states is not established - is almost entirely based on the statements provided by two Catalan voters who explain the violence that they witnessed. This means that the journalist selects a part of the reality in favor of Catalonia and shows it as the total truth, which leads to misinformation. In addition, the text lacks of any type of contextualization, what makes readers more likely to accept the daily's stance as valid since they do not have the possibility to understand clearly the reasons for this conflict.

Thus, the particular characteristics of this article - the use of sensational words; the absence of contextualization; the almost exclusive inclusion of statements just from one of the two sides involved in the facts; the focus on the violent scenes; and the brevity of the text, which consists only of five paragraphs - together with the apolitical nature of the free press in Switzerland (fög, 2012) give the impression of a text that has been written in a fast way and whose main objective is, rather than inculcating a concrete position on the issue to the reader, achieving impact and audience.

The free [Swiss] media have turned tabloid-style journalism from a rather circumscribed and limited phenomenon into the journalistic mainstream. And this mainstream 
is neither left nor right-leaning; it mainly consists of episodic journalism and soft news and favours coverage of those actors who fit this profile. (fög, 2012, p. 2)

\section{Conclusions}

The informative coverage of the Catalan referendum shows great differences depending on the social, political and cultural reality of the territories in which the analysed media outlets operate, as well as on the editorial line of each newspaper. The diversity of points of view when addressing the data related to nationalism can be considered logical, since, as McQuail (1984, p. 108) states, journalistic objectivity "is both necessary and impossible" and the reading of different sources of information with different perspectives can help the reader to form a personal and solid opinion. The problem is that many individuals consume only the information close to their own thoughts (Happer \& Philo, 2013) and tend to reject everything the media says that goes against their opinions, which results in the formation of an uncritical and vulnerable society.

The danger that this type of information consumption poses to the population is evident taking into account that most of the newspapers analysed in this study manipulated the information, so that their points of view could gain social support, and showed only a part of reality as absolute truth, using lexical tools that reinforce a favorable stance towards the Spanish or Catalan sides, inculcating ideas into society and even teaching them models of behaviour.

This piece of research shows that the editorial line of all the analysed newspapers transcends their digital versions and that those located in countries with pro-independence tensions (The Sun, UK; The Daily Record, Scotland, Corriere della Sera, Italy, and Il Gazzettino, Northeast Italy) are more likely to inculcate their concrete stance in a way that often infringes the journalistic ethics.

The latter frame - through the lexical choices, the over-lexicalization and the quoting verbs - certain ideas that indicate a position favorable to the Catalan independence (Il Gazzettino), to a process of pro-devolution in the region (The Daily Record) or to the state unity (The Sun and Corriere della Sera). However, it is necessary to specify that these four newspapers - although, to a greater extent, those which operate in concrete regions with a strong nationalist sentiment - make a frequent use of other communication strategies that strengthen their positions and imply a lack of informative accuracy. In this way, some frames are reinforced by the total absence of contextualization ( $I l$ Gazzettino); a misleading historical contextualization (The Daily Record); the contribution of data related just to one of the two sides of the conflict, as well as the unequal reflection of each side's stance (The Sun, The Daily Record, Il Gazettino); the intended inclusion (The Sun) or exclusion (Il Gazzettino, The Daily Record) of pronouns like "we" or "them", with which the newspapers seek to increase or reduce the impression of informative proximity; or the explicit manifestation of the journalist's opinion in the text (Corriere della Sera).

For its part, the Portuguese Correio da Manhã also makes use of certain lexical choices, over-lexicalization and quoting verbs that reflect a position favorable to the unity of Spain, what coincides with the newspaper's centre-right political stance. However, besides using a more balanced and informative language than the previous dailies, it also offers an adequate social and political contextualization of the facts and includes numerous declarations made by different actors from the Catalan and Spanish sides, which could be due to the more favorable situation of Portugal in terms of independence issues.

Special mention deserves the information published by 20 Minuten. The informative coverage carried out by the free Swiss newspaper keeps certain similarities with that of $\mathrm{Il}$ Gazzettino and The Daily Record in terms of language, lack of contextualization and bias. However, the apolitical nature of the free press in Switzerland, together with the briefness of the content published on these facts by the 
tabloid, suggests that the rather sensationalist and short treatment done by $20 \mathrm{Mi}$ nuten simply attends to the search for impact and audience. Under this interpretation, the social and political influence of the newspaper's article - that exaggerates both the suffering of the voters and the police violence, making readers more likely to support the independence of Catalonia - could be understood as unintended, what leads to question the potential consequences that the information published by the free media can cause on society.

Ultimately, this information treatment presents risks for social stability in Europe, since the representation of different realities carried out by the main media outlets can generate individualism and also radicalization in certain regions of the European continent; a geographical area that, especially as a result of the economic crisis in 2008, has experienced a resurgence of nationalism, so that the lack of objectivity about the political problems abroad could initiate a contagion or domino effect.

However, it is necessary to point out that the conclusions presented in this study are the result of a limited analysis, since only the online version of the best-selling newspapers in six different territories is considered, using Critical Discourse as a research method, which involves a certain degree of subjectivity. Thus, this piece of research aims to serve as a small contribution in the coverage of nationalism in Europe and is open to be further developed in future research. It is a broad topic that needs to be studied more thoroughly through the analysis of more types of media outlets and more publications related to both the Catalan conflict and other social and political facts related to this issue.

\section{References}

Armstrong, J. A. (2000). Nations before nationalism. In J. Hutchinson and A. D. Smith (Eds.), Nationalism: Critical concepts in political science (Vol. 1, pp. 216-243). London, UK: Routledge.
Borgen, C. (2007). Imagining sovereignty. Managing secession: The legal geography of Eurasia's “frozen conflicts”. Oregon Review of International Law, 9, 477-535.

Brubaker, R. (1996). Nations reframed: nationhood and the national question in the new Europe. Cambridge, UK: Cambridge University Press.

Castelló, E., León-Solís, F., \& O’Donell, H. (2016). Spain, Catalonia and the Scottish referendum: a study in multiple realities. In N. Blain, D. Hutchison, \& G. Hassan (Eds.), Scotland's referendum and the media: national and international perspectives (pp. 159-172). Edinburgh, UK: Edinburgh University Press.

Cazzullo, A. (2017, October 1). Referendum in Catalogna, la catena degli errori [Referendum in Catalonia, the chain of errors]. Corriere della Sera. Retrieved from: https://www.corriere.it/esteri/17_ottobre_02/catalogna-catena-errori-f749c664a6e5-11e7-a0ff-6d279b95c0af.shtml

Colley, A. (2017, October 1). Catalonia riot cops storm polling stations and "fire rubber bullets at voters" in bid to stop banned independence referendum. The Daily Record. Retrieved from: https:// www.dailyrecord.co.uk/news/uk-worldnews/catalonia-riot-cops-storm-polling-11268946

Connolly, C. (2013). Independence in Europe: Secession, sovereignty, and the European Union. Duke Journal of Comparative \& International Law, 24(1), 51-105.

Connor, W. (1989). Democracia, etnocracia, y el estado multinacional moderno: paradojas y tensiones [Democracy, ethnocracy, and the modern multinational state: paradoxes and tensions]. In A. Pérez-Agote (Ed.), Sociología del nacionalismo [Sociology of nationalism] (pp. 111-130). Bilbao, Spain: Universidad del País Vasco.

Correia, C., \& Figueiredo, C. (2017, October 1). Sim à independência vence com $90 \%$ dos votos na Catalunha [The "yes" to independence wins with $90 \%$ of votes in Catalonia]. Correio da Manhã. Retrieved from: https://www.cmjornal.pt/mundo/ detalhe/urnas-ja-estao-nas-escolas-ecatalaes-fazem-filas-para-votar

Correia, F., \& Martins, C. (2018). Portugal - Media landscape. Maastricht: Media Landsca- 
pes. Available at: https://medialandscapes. org/country/pdf/portugal

Dandoy, R. (2010). Ethno-regionalist parties in Europe: A typology. Perspectives on Federalism, 2(2), 194-220.

Dekavalla, M. (2016). Framing referendum campaigns: The 2014 Scottish independence referendum in the press. Media, Culture and Society, 38(6), 793-810.

Deutsch, K. W. (1953). Nationalism and social communication: An inquiry into the foundations of nationality. New York: The Technology Press of the Massachusetts Institute of Technology.

De Vreese, C. (2005). News framing: Theory and typology. Information Design Journal, 13(1), 51-62.

Entman, R. M. (1993). Framing: Toward clarification of a fractured paradigm. Journal of Communication, 43(4), 51-58.

Esman, M. J. (1994). Ethnic politics. Ithaca, NY: Cornell University Press.

Knüsel, N. (2017, October 1). «Solche Brutalität hat niemand erwartet» ["Nobody expected such brutality"]. 20 Minuten. Retrieved from: https://www.20min.ch/ausland/ news/story/-Solche-Brutalitaet-hat-niemand-erwartet--28540847

Evangelisti, M. (2017, October 1). Catalogna, strappo nel caos. Martedì lo sciopero generale [Catalonia, tear in chaos. Tuesday the general strike]. Il Gazzettino. Retrieved. from:https://ilgazzettino.it/esteri/referendum_catalogna_gente_fila_alba_voto_polizia_spagnola-3273711.html

Fairclough, N. (1993). Critical discourse analysis and the marketization of public discourse: The universities. Discourse \& Society, 4(2), 133-168.

Fearon, J., \& Van Houten, P. (2002, May 10-11). The politicization of cultural and economic differences. A return to the theory of regional autonomy movements. Paper presented at the Fifth Meeting of the Laboratory in Comparative Ethnic Processes (LiCep), Stanford, CA.

Firmstone, J. (2018). United Kingdom - Media landscape. Maastricht, NL: Media Landscapes. Available at: https://medialandscapes.org/country/pdf/united-kingdom

Flew, T. (2007). Understanding global media. New York: Palgrave Macmillan. fög - Forschungsbereich Öffentlichkeit und Gesellschaft [Center for Research on the Public Sphere and Society]. (2012). Yearbook 2012: the quality of the mediaSwitzerland. Retrieved from: https:// www.foeg.uzh.ch/dam/jcr:fffffff-db29f6ba-0000-000063301eae

Friemel, T. N., \& Dötsch, M. (2015). Online reader comments as indicator for perceived public opinion. Kommunikationspolitik für die digitale Gesellschaft, 1(8), 151-172.

Garrett, G., \& Rodden, J. (2003). Globalization and fiscal decentralization? In M. Kahler and D. Lake (Eds.), Governance in a global economy: political authority in transition. Princeton, NJ: Princeton University Press.

Gramsci, A. (2011). Prison notebooks. New York, NY: Columbia University Press.

Guibernau, M. (1998). Catalan nationalism and the democratization process in Spain. In K. Cordell (Ed.), Ethnicity and democratization in the new Europe (pp. 77-90). London, UK: Routledge.

Hansen, A., \& Machin, D. (2013). Media and Communication Research Methods. London, UK: Palgrave Macmillan.

Happer, C, \& Philo, G. (2013). The role of the media in the construction of public belief and social change. Journal of Social and Political Psychology, 1(1), 321-336.

Hayes, J. E. (2000). Radio nation: Communication, popular culture, and nationalism in Mexico 1920-1950 (2 ${ }^{\text {nd }}$ ed.). Tucson, AZ: University of Arizona Press.

Hodge, R., \& Kress, G. (1988). Social semiotics. Cambridge, UK: Polity Press.

Hutchison, I. G. C. (2002, August 18-24). Scottish Newspapers and Scottish National Identity in the Nineteenth and Twentieth Centuries. Paper presented at the $68^{\text {th }}$ IFLA Council and General Conference, Glasgow, UK.

Jiménez, J. (2017, October 2). Interior confirma que 431 policías y guardias civiles resultaron heridos en el 1-O [Interior confirms that 431 police and civil guards were injured on 1-O]. Okdiario. Retrieved from: https://okdiario.com/espana/ cataluna/2017/10/02/interior-confirma-431-policias-guardias-civiles-resultaron-heridos-1-1377999 
Johansonn, Sofia. (2007). Reading tabloids: Tabloids and their readers. Huddinge, Sweden: Södertörnhogskola.

Jolly, S. (2015). The European Union and the rise of regionalist parties. Ann Arbor, MI: University of Michigan Press.

Kavoori, A., \& Chadha, K. (2009). The cultural turn in international communication. Journal of Broadcasting \& Electronic Media, 53(2), 336-346.

Keating, M. (2013). Rescaling Europe. Oxford: Oxford University Press.

King, S. (2014). “Goodbye, Spain?” The question of independence for Catalonia. Journal of Iberian and Latin American Research, 20(3), 480-482.

Lee, S. (2003, May 27). Beyond cultural boundary: an empirical study of the third culture theory. Paper presented at the Annual Meeting of the International Communication Association, Marriot Hotel, San Diego, CA. Retrieved from: http://www.allacademic.com/meta/p112182_index.html

Machin, D., \& Mayr, A. (2008). How to do critical discourse analysis. London, UK: Sage.

Mancini, P., \& Gerli, M. (2018). Italy - Media landscape. Maastricht: Media Landscapes. Available at: https://medialandscapes.org/ country/pdf/italy

McCombs, M. (2014). Setting the agenda: mass media and public opinion ( $2^{\text {nd }}$ ed.). Hoboken, NJ: Polity Press.

McQuail, D. (1984). Communication. London, UK: Longman.

Meier, W. (2018). Switzerland - Media landscape. Maastricht: Media Landscapes. Available at: https://medialandscapes.org/ country/pdf/switzerland

Mihelj, S. (2011). Nationalism and the media, east and west. In M. Sükösd \& K. Jakubowicz (Eds.), Nationalism, the Media and European Identity (pp. 203-226). Budapest, Hungary: Central European University Press.

Morley, D., \& Robins, K. (1995). Spaces of identity: Global media, electronic landscapes and cultural boundaries. London, UK: Routledge.

Nederveen, J. (2015). Globalization \& culture ( $3^{r d}$ ed.). London, UK: Rowman \& Littlefield.
Orgad, S. (2012). Media representation and the global imagination. Cambridge, UK: Polity Press.

Patel, F., Li, M., \& Sooknanan, P. (2011). Overview of intercultural communication. In Patel, F; Li, M; \& Sooknanan, P. (eds.), Intercultural Communication: Building a Global Community (pp. 15-38). New Delhi, India: Sage.

Peña-Fernández, S., Lazkano-Arrillaga, I., \& García-González, D. (2016). European newspaper's digital transition: new products and new audiences. Comunicar, 24(46), 27-35.

Pouthier J. L. (2010). Frères d'Italie: la difficile unité [Brothers of Italy: The difficult unity]. Études, 413, 583-593.

Revest, D. (2016). The French view. In N. Blain, D. Hutchison \& G. Hassan (Eds.), Scotland's referendum and the media: National and international perspectives (pp. 173181). Edinburgh, UK: Edinburgh University Press.

Rondinelli, D., Nellis, J. R., \& Cheema, G. S. (1984). Decentralization in developing countries: A review of recent experience. Washington, DC: World Bank.

Sandeman, G. (2017, October 1). World condemns violence as Catalonia chief claims independence poll victory. The Sun. Retrieved from: https://www.thesun.co.uk/ news/4586709/catalonia-won-right-independence-police-crackdown-protesters/

Smith, A. D. (1995). Nations and nationalism in a global area. Cambridge, UK: Polity Press.

Tarrow, S. (2011). Power in movement. Cambridge, UK: Cambridge University Press.

Van Dijk, A, T. (1995). Aims of critical discourse analysis. Japanese Discourse, 1, 17-27.

Thadeshwar, S., \& Joglekar, A. (2016). Impact of online news media on consumption habits of people. International Journal of Advanced Research in Computer Engineering \& Technology, 5(3), 564-568.

Titscher, S., Meyer, M., Wodak, R. \& Vetter, E. (2000). Methods of text and discourse analysis: In search of meaning. London, UK: Sage.

Türsan, H. (1998). Introduction. Ethnoregionalist parties as ethnic entrepreneurs, In D. W. Lieven \& T. Huri (Eds.), Regionalist parties in Western Europe (pp. 1-16). London, UK: Routledge. 
Williamson, K., \& Golding, P. (2016). The

English press and the referendum. In

N. Blain, D. Hutchison \& G. Hassan (Eds.),

Scotland's referendum and the media:

national and international perspectives

(pp. 109-120). Edinburgh, UK: Edinburgh

University Press. 